\title{
Nationalism and Religion
}

\section{March 1996/2 Dhü al Qa'dah 1416}

\section{London School of Economics, University of London, London, UK}

Following the spectacular disintegration of the Soviet Union, popular and academic interest in nationalism and religion gathered momentum. In addition to recent ethnic clashes and religious conflicts in many parts of the world, particularly the Balkans, Central Asia, the Middle East, and many African states, questions have been raised about the relation between nationalism and religion. What, if any, is the relationship between nationalism and religion? To what extent can religion influence the emergence and maintenance of nationalism? Can religious beliefs and sentiments legitimize a nationalist ideology? What is meant by "religious nationalism," and how is it related to nation-states, resistance, and violence? These questions were addressed during a one-day conference held at the London School of Economics, University of London on 22 March 1996. The well-attended conference was organized by the Association for the Study of Ethnicity and Nationalism, which was established in 1990 and has published the journal Nations and Nationalism since March 1995.

The first paper at the Nationalism and Religion conference was presented by Bruce Kapferer (University College of London, London, UK). In his paper "Religious and Historical Metaphors in the Context of Nationalist Violence," he addressed political action, the force of ideologies, and the relevance of mythological schemes to religious and ritual practice by means of a case study of Sinhalese Buddhists in Sri Lanka and the events of 1989-90. In his own words, his focus was "the dynamics of remythologization, or the process ... whereby current political and economic forces are totalized within mythological schemes constructed in historical periods relatively independent of the circumstances of contemporary nationalism" and "the force of such ideological remythologizations, that is, how such remythologizations can became a passionate dimension of political activity and give it direction."

According to Kapferer, the relation of mythologization to routine religious beliefs and ritual practice is significant. In his paper, he argued that "nationalism is the creation of modernism and it is of a continuous dynamic nature whose power is embedded in and sanctified by the culture that has originated in the rituals of religion which provide a cosmology for nationalism. Cosmology of religion as diverse as nationalism itself that is far from universal claims but exists in diversity." Kapferer's theorization is based on his research in Sri Lanka where, he thinks, continuing conflict is related to nationalism based on cosmologies. The case of Sri Lanka provides an 
excellent example of how the construction of state ideology is influenced by religious forces, in this case Buddhism. Kapferer asserted that religion had a deep territorialization aspect and that nationalism, in this sense, might have functioned as reterritorialization of a particular land and postcolonial state. One can discern from his statements that, in the construction of state ideology in Sri Lanka, myths written by monks and religious rituals were used to create a nationalist movement that eventually developed into a violent and destructive force in the context of Sri Lanka. Kapferer believes that the hierarchical order of the Sri Lankan state is embedded in the cosmology of ancient religious chronicles.

Christopher Cviic (The Royal Institute of International Affairs, London, UK) analyzed another phenomenon taking place in Western Europe. His paper, "Chosen Peoples and Sacred Territories: The Balkans," discussed the relationship between religion, nation, and state in the Balkans throughout history and analyzed how these forces have played themselves out in current events. According to Cviic, historical developments in the Balkans can provide important clues to understanding the ongoing Balkan crisis, in which the Orthodox Church has assumed the status of a nationalist institution representing the Serbian nation. The roots of these developments and the creation of a mythical "chosen" Serbian nation legitimized by religion can be traced to the defeat and fall of medieval Serbia at Kosova by the Ottomans. This defeat meant that they lost the land.

However, under the Ottoman millet system, non-Muslim communities were allowed to organize their religious life and legal and educational institutions. This allowed the Serbs to preserve and develop their ethnic and religious identities under the leadership of the Orthodox Church. Thus, religion and identity became inextricably linked, and the Orthodox Church assumed an extremely important role in the public life of individual Balkan nations. Cviic pointed out that "in the case of the Serbs, their Orthodox Church played an important role in the formation of the modern Serbian nation-state by nurturing the myth of Kosova, named after the Kosova Polje defeat by the Turks. Essential to that myth was the view that by choosing to fight at Kosova Polje, the Serbs had opted for the Kingdom of Heaven. Later on the myth grew into a broader one, representing the Serbs as the martyr/victim people with a sacred mission of wresting their Holy Territory of Kosova from the infidel Muslims to whom it had fallen. A later variant of that myth defined Serbia in terms of wherever Serbian graves were to be found."

World War II losses gave Serbians another experience that revived their sense of martyrdom. This became a forceful element in post-1945 Yugoslavia, where religious writings compared the Serbs, as a "chosen people," to the Jews. Cviic argued that all these themes and myths have been used in the current war to the extent that anything symbolizing Islam (e.g., mosques) was reduced to rubble by the force of hate reinforced by an Orthodox Church that sided openly with Radovan Karadzic. Cviic also 
noted that intellectuals and politicians are very much preoccupied with the revival of Islam and that everybody talks about "Islamic fundamentalism" while turning a blind eye to Orthodox fundamentalism within the context of contemporary religion and politics.

The use of violence and the role of religion and nationalism in its emergence were addressed by John A. Armstrong (University of Wisconsin-Madison, USA) in his paper "Religious Nationalism and Collective Violence." He told the audience that "religion and nationalism are part of a continuum. One cannot be understood without the other. Religion and nationalism appeal to strong sentiments of identity." Armstrong believes that violence arises not only from terrorism by nationalist movements that lack legal authority, but also more extensively from patriotism inculcated by regimes. Cycles of intense religious nationalism emerged as early as the Roman empire and were followed by violent secular nationalism.

In Armstrong's opinion, ethnoreligious violence was widespread during the Reformation. However, during the last two centuries, confrontations between traditional religions and secular ideologies have been most violent. Toward the end of the nineteenth century, for example, secularists rejected totally the religious clericalism of the Catholic establishment as a step toward eliminating religion from political and public life. Armstrong pointed out that Social Darwinism legitimized the resort to extreme violence, including genocide, that traditional religions always had rejected. On the other hand, Marxism-Leninism produced totalitarian regimes that excelled in external and internal violence, as observed during the collapse of the Soviet Union due, in part, to nationalism. While nationalist movements gathered momentum in the Soviet Union, religious leaders in Georgia, Armenia, Azerbaijan, and other Soviet-ruled areas resurfaced in the public sphere and motivated their people to struggle for independence.

Armstrong expressed skepticism toward the force of "civil religion" in liberal constitutional states to mobilize citizens for the immense sacrifices required even for defensive warfare in modern conditions. Giving a complex picture of events taking place in Eastern Europe and the former Soviet Union, Armstrong asked whether democracy can resolve the conflict situation in these troubled regions in which religion and nationalism constitute a continuum.

Eileen Barker's (London School of Economics, University of London, UK) "The National Church and Other Religions" discussed the role of religion in officially atheist Eastern and Central Europe and the former Soviet Union. She noted that, in the early 1990s, these societies had a common expectation that religion would fill the vacuum left by the collapse of Marxism. The question raised by the changing circumstances was, "Which religion?," as Barker indicated correctly. She pointed out that "the national churches were increasingly of the opinion that, just as a father who has been unlawfully imprisoned should, on release, have the 
right to embrace his orphaned children, they should not be expected to countenance the presence of competitors who have access to resources unavailable to the rightful parent. It was not long before the honeymoon of an unambiguous concept of religious freedom was over, and battle had commenced." Drawing upon her research in Armenia, she suggested that religion and nationalism were bound together in such a way that they react to each other and produce one another. Such a theorization could be attributed, as she claimed, to the fact that in Eastern Europe, and especially in Armenia, Christianity is not related to Jesus but rather is closely linked to national memories, identity, and belonging. Such religious symbols as "holy land," "chosen people," suffering, and martyrdom are used constantly in conflict situations. Barker noted that Armenia's mother church/national church uses religion to clarify and strengthen the boundaries between "us" and "them." Therefore, paramilitary groups desacralized and destroyed sacred buildings and sites of rival religions seen as belonging to "them."

The emergence of nationalism and its relation to religion in the Muslim world was addressed by Sami Zubaida (Birkbeck College, University of London, UK) in "Islam and the Nation-State." Zubaida outlined the emergence of nation-states in the Middle East in the postcolonial era and asserted that modern Middle Eastern states did not have a secular nature. He said, "Nowhere has religion been separated from the state, even in secular Turkey. What Ataturk, founder of modern Turkey, did was to subordinate religion to the state and prohibit its use as political ideology. In Republican Turkey religion was contained within the state as exemplified by the existence of Directorate of Religious Affairs as a vast state bureaucracy." Moreover, he continued, the nationalist regimes of Nasser in Egypt and the Bathists in Iraq and Syria have tried similarly to control religious institutions in order to prevent religious advocacy by opposing forces. Zubaida calls this an ideological exploitation of Islam, something that is not new in the Middle East.

Political struggles for and against the ruling authorities, he pointed out, "have drawn on Islam for their advocacy, and in this way Islam has been 'ideologized' since the early nineteenth century. As such, it was closely tied up with the emergence and development of nationalism in all countries of the Middle East. Populist appeals have drawn upon sentiments of religious communitarianism and sectarianism." Zubaida supported his claims with examples from Turkey, Iran, Iraq, and Egypt, where nation-states produced religiously inspired political movements that utilized the Islamic "idiom" and "discourse" in their struggle.

The last paper of the conference, Liah Greenfeld's (Boston University, USA) "Nationalist Religions, Religious Nationalisms and the Aspiration of Modernity," argued that "religious nationalism is one of the methods in which religion is harnessed to nationalist political interests. Religious nationalisms fall into civic and ethnic subtypes of collectivistic nationalism, but are more likely to be ethnic, which help to account for 
the zealous and violent temper by which they are often characterized." She attributed the emergence of vigorous nationalism to the less inhibited expressions of nationalist sentiments, in general, and ethnic nationalism, in particular, due to the collapse of communism. On the other hand, it is also attributable to the temporary unavailability of other ideological options. While discussing instances of religious nationalism in the contemporary world, as in the recent crisis in Bosnia, she pointed out that Bosnians were denied any other identity but Islam. They were seen as responsible for their Muslim ancestors' victory over Serbians, and they were victimized accordingly.

Talip Kucukcan Centre for Research in Ethnic Relations University of Warwick Coventry, UK 